DE

M E D I C I N A

T R O P I C A L

$\mathrm{DE}$

SÃO PAULO

JOURNAL OF THE SÃO PAULO INSTITUTE OF TROPICAL MEDICINE

(1)Instituto Oswaldo Cruz (FIOCRUZ), Laboratório de Diptera, Rio de Janeiro, Rio de Janeiro, Brazil

(2)Universidade Federal Rural do Rio de Janeiro, Instituto de Biologia, Programa de Pós Graduação em Biologia Animal, Seropédica, Rio de Janeiro, Brazil

(3)Instituto Oswaldo Cruz (FIOCRUZ), Laboratório de Transmissores e Hematozoários, Rio de Janeiro, Rio de Janeiro, Brazil

${ }^{(4)}$ Instituto Federal do Norte de Minas Gerais, Salinas, Minas Gerais, Brazil

${ }^{(5)}$ Entomologistas do Brasil, EntomoBrasilis, Vassouras, Rio de Janeiro, Brazil

Correspondence to: Jeronimo Alencar Instituto Oswaldo Cruz (FIOCRUZ), Laboratório de Díptera, Av. Brasil, 4365, CEP 21040-360, Manguinhos, Rio de Janeiro, RJ, Brazil

Tel: + 5521 2562-1238

E-mail: jalencar@ioc.fiocruz.br

Received: 10 January 2017

Accepted: 31 March 2017

\section{Oviposition behavior of Haemagogus leucocelaenus (Diptera: culicidae), a vector of wild yellow fever in Brazil}

\author{
Aline Tátila-Ferreira ${ }^{1,2}$, Daniele de Aguiar Maia', Filipe Vieira Santos de \\ Abreu $^{3,4}$, William Costa Rodrigues ${ }^{5}$, Jeronimo Alencar ${ }^{1,5}$
}

\section{ABSTRACT}

Haemagogus leucocelaenus, which is considered a major vector of wild yellow fever, exhibits acrodendrophilic habits and mainly deposits its eggs in treeholes and bamboo internodes. The selection of nursery sites is essential in the life history and reproductive success of mosquitoes. The present work investigated the preferred oviposition height and period of $\mathrm{Hg}$. leucocelaenus in an Atlantic forest area in Rio de Janeiro. Sampling was performed using oviposition traps that were placed on plant material at $0,2,4,6$, and 8 $\mathrm{m}$ above the ground, from August 2015 to July 2016. Eggs were more abundant during October and May, and the height of traps placement had no significant effect on the eggs number indicating that $\mathrm{Hg}$. leucocelaenus explores different levels of forest habitats, a behavior that may favor the transmission of pathogens among arboreal animals including primates and humans. The findings of the present study are discussed from an ecological and epidemiological point of view.

KEYWORDS: Acrodendrophily. Culicidae. Height preference. Oviposition trap. Yellow fever vectors.

\section{INTRODUCTION}

Oviposition behavior and the selection of nursery sites are essential components of the life history of mosquito species and are closely related to the survival of immature mosquitoes ${ }^{1}$, since larvae are unable to move to different sites when facing unfavorable conditions $\mathrm{s}^{2,3}$. The selection of nursery sites may also affect the larval development and growth, as well as their vulnerability to predation, access to food and, ultimately, phenotype and fitness ${ }^{1,4,5}$. As a result, there is a great selective pressure that favors females that promote the survival of their offspring ${ }^{5}$.

Many members of the Culicidae complete their larval cycle in temporarily flooded environments, such as felled or hollow trees and bamboo and are susceptible to variation in nursery patterns 6 . In addition, members of the genus Haemagogus, including Hg. leucocelaenus (Dyar \& Shannon, 1924), are usually wild, active during the day, and exhibit acrodendrophilic habits ${ }^{7-9}$. However, Hg. leucocelaenus has been reported to exhibit a greater ability to survive in modified environments in the North and West borders of São Paulo than both its congeners and Aedes albopictus (Skuse, 1894), which occur in the same areas; Hg. leucocelaenus may facilitate the transmission of yellow fever virus in urban areas ${ }^{10}$.

In Brazil, the Culicidae are common and important epidemiologically, owing to their ability to spread arboviruses, including yellow fever ${ }^{11,12}$. Figueiredo $e t a l .{ }^{13}$ reported the presence of $\mathrm{Hg}$. leucocelaenus at Coribe, Southwest of Bahia, using 
real-time nested-PCR, with primers targeting DENV-1, which underlines the importance of studying the virus in wild mosquitoes. Despite the lack of reported cases of yellow fever in Rio de Janeiro for several decades, the disease has been spreading to the South and East and has been documented in areas that were previously considered free of the virus, such as the States of São Paulo ${ }^{14,15}$ and Minas Gerais ${ }^{16}$, both bordering Rio de Janeiro. Therefore, understanding the diverse aspects related to this vector in the Atlantic forest region of Rio de Janeiro may help establishing a more efficient surveillance system for this disease.

\section{MATERIALS AND METHODS}

\section{Ethics statement}

The research was performed in accordance with the scientific license number 34911 provided by SISBIO/ IBAMA (Authorization and Information System on Biodiversity/Brazilian Institute of Environment and Renewable Natural Resources) for the capture of culicids throughout the Brazilian national territory.

\section{Study area}

The Mata Atlântica FIOCRUZ Campus (CFMA) encompasses nearly 500 ha and is situated in the West zone of the Rio de Janeiro municipality, State of Rio de Janeiro, S $22^{\circ} 56^{\prime}$ and $\mathrm{W} 043^{\circ} 25^{\prime}$. The entire Western portion of CFMA belongs to an environmental conservation area and is characterized by dense and ombrophilous secondary Atlantic forest. Wild animals, such as nonhuman primates, sloths (Folivora), snakes (Ophidia), skunks (Didelphimorphia), armadillos (Cingulata), lizards (Sauria), toucans (Piciformes), and parrots (Psittaciformes), are found in this protected area and are observed around populated areas, as well ${ }^{17}$. Eight biotopes have been described in the campus area, including Atlantic forest (secondary forest, at elevations $>100 \mathrm{~m}$ ), regeneration forest (secondary forest, trees and dense forest), groves (tree-shrub vegetation), subsistence culture, pasture or weed fields (grass, some shrubs, and small trees), rocky outcrops, flooded forest (groups of trees, with periodic flooding), and urban or deforested area $^{17}$.

\section{Specimen collection}

Previous reports have successfully used oviposition traps with wide openings to collect eggs from $\mathrm{Hg}$. leucocelaenus and $\mathrm{Hg}$. janthinomys ${ }^{18-20}$. Following the methodology proposed by Silver ${ }^{21}$, monitoring was conducted through the use of Ovitrap oviposition traps ${ }^{22,23}$, each of which consisted of a black 1-L container with four $2.5 \times 14 \mathrm{~cm}$ plywood panels (Eucatex boards) that were placed vertically inside the trap and held in place using clips. In addition, traps also contained water and organic matter, which were added to encourage oviposition.

Eggs of $\mathrm{Hg}$. leucocelaenus were collected during 12 consecutive months, from August 2015 to July 2016. The oviposition traps were distributed in two locations, and at each location, individual traps were placed at $0,2,4,6$, and $8 \mathrm{~m}$ above ground level $(\mathrm{n}=5)$. The plywood panels were replaced fortnightly and the collected panels were labeled, placed in a moist chamber and transported to the Diptera Laboratory at the Oswaldo Cruz Institute for analysis.

\section{Breeding and identification of mosquitoes}

Panels with eggs were immersed in Milli-Q water in transparent trays and then incubated for $3 \mathrm{~d}$ at $28 \pm 1^{\circ} \mathrm{C}$, with a relative humidity of $75-90 \%$ and a photoperiod of $14 \mathrm{~h}$. Afterwards, the panels were transferred to dry trays for approximately 3-4 d, outside the incubator, then submerged again to end the embryonic development.

At the time the mosquitoes reached the adult phase, identification was performed based on morphological characteristics, using a stereomicroscope (ZEISS Stemi SV6) and the dichotomous keys of Arnell ${ }^{7}$, Forattini ${ }^{24}$, and Marcondes and Alencar ${ }^{9}$. Finally, all the specimens were added to the Entomologic Collection at the Oswaldo Cruz Institute, FIOCRUZ, under the identification "Coleção Mata Atlântica - Rio de Janeiro" (Atlantic Forest Collection Rio de Janeiro).

\section{Statistical analysis}

The data were first analyzed using the Shapiro-Wilk normality test. Data with normal distribution were submitted to the analysis of variance (ANOVA), using the Fisher (F)-test to compare the oviposition (number of eggs) at different heights and to compare oviposition during different months. In addition, the correlation between oviposition (number and frequency) at different heights was tested using the Pearson correlation test. The data were grouped using the Cluster (K means) method to verify the association between flight height and months under study. All the analyses were performed using $\mathrm{R}^{25}$ (R Core Team Program) and various packages within Econometric tools for performance and risk analysis: PerformanceAnalytics, eXtensible Time Series, Grammar of Graphics, Political Science Computational Laboratory, 
Polychoric and Polyserial Correlations, and Visualization of a Correlation Matrix.

\section{RESULTS}

A total of 4,553 eggs were collected over the yearlong experiment. More eggs were obtained during October ( $16.87 \%$ of total) and May $(15.13 \%)$ than during the other months, and the smallest numbers of eggs were obtained during December (1.36\%) and July (1.56\%). Furthermore, all eggs were identified as $\mathrm{Hg}$. leucocelaenus.

Trap height did not significantly affect oviposition (F-value >0.05; Table 1). However, there was a significant and positive correlation between trap height and absolute abundance of the traps at $0,4,6$, and $8 \mathrm{~m}(p<0.01), 0$ and $2 \mathrm{~m}(p<0.05)$, and 0 and $6 \mathrm{~m}(p<0.05$; Figures 1 and 2$)$. Meanwhile, cluster analysis grouped months from different seasons (e.g., May and October) and traps at non-adjacent heights (e.g., 0 and $4 \mathrm{~m}$ ); however, the analysis did group the higher traps $(6$ and $8 \mathrm{~m})$ and lower traps $(0,2$, and $4 \mathrm{~m}$; Figure 3).

In contrast, when considering the month as the independent variable, a significant difference was observed
(ANOVA; Table 2), and the Tukey test indicated that there were significant differences $(p<0.05)$ in the abundance of specimens observed during May and December, October and December, May and July, October and July, and October and January. There was only a significant and negative correlation $(r=-0.94)$ between May and October, and there was independence of occurrence between the remaining months. When comparing flight heights and climate factors (a week before and in the same week), there was no correlation between climate factors and the parameter used (flight height).

\section{DISCUSSION}

Haemagogus leucocelaenus is considered an important vector of wild yellow fever in the Southeast Brazil, where the occurrence of $\mathrm{Hg}$. janthinomys is limited. Data from the present study have reported, for the first time, as far as we know, the abundance of $\mathrm{Hg}$. leucocelaenus within an urban forest fragment in an area of Atlantic forest. The great number of collected eggs and the presence of eggs throughout the collecting period, which included both dry and rainy seasons, demonstrate the ability of

Table 1 - Analysis of variance (ANOVA), using trap height as the treatments and months as repetitions

\begin{tabular}{lccccc}
\hline & df & Sum Sq & Mean Sq & Critical F* & Pr $(>\mathrm{F})$ \\
\hline Treatment & 4 & 2570 & 642 & 2.5397 & 0.951 \\
Residuals & 55 & 203,159 & 3694 & & \\
\hline
\end{tabular}

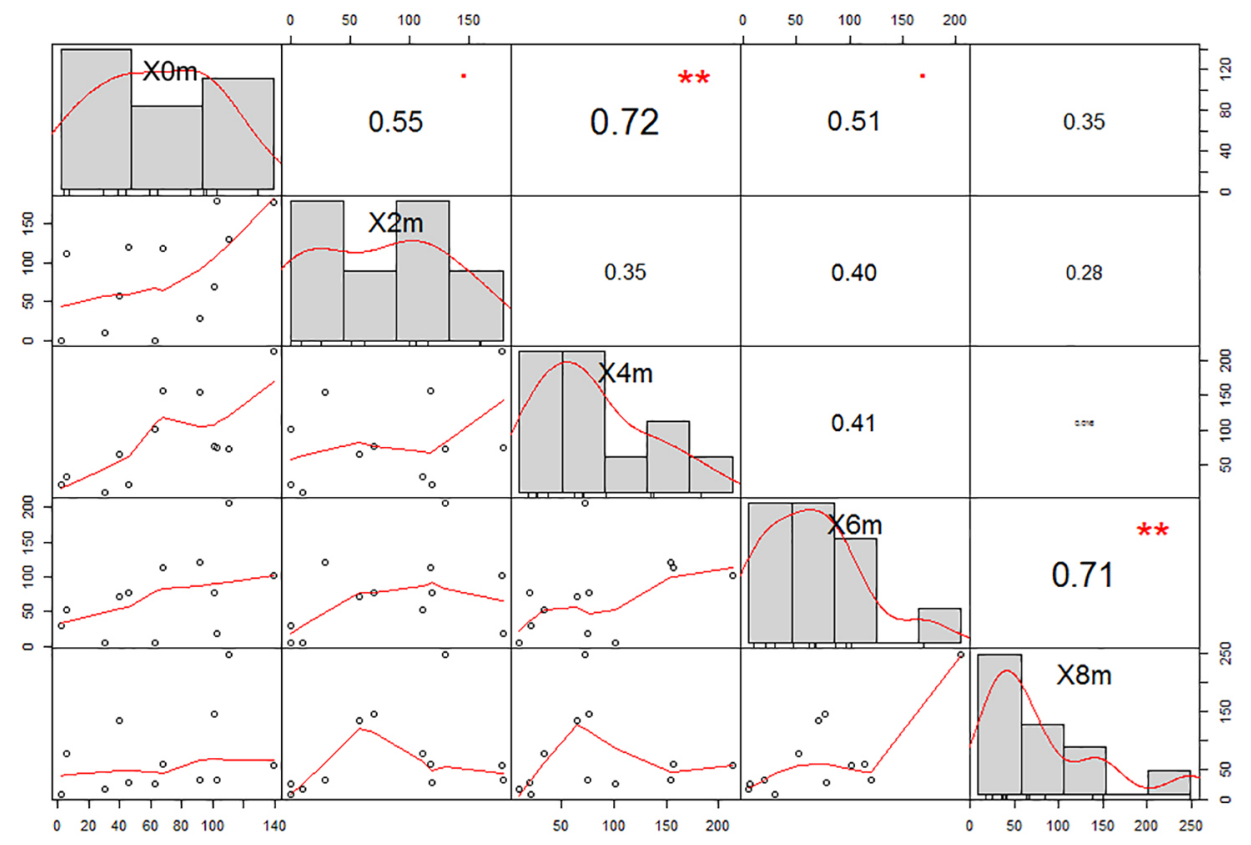

Figure 1 - Data dispersion matrix of flight heights, with their respective Pearson correlation values. Significance $\left({ }^{*}, 0.05 ;{ }^{* *}, 0.01\right.$; $\star * \star, 0.001)$ 


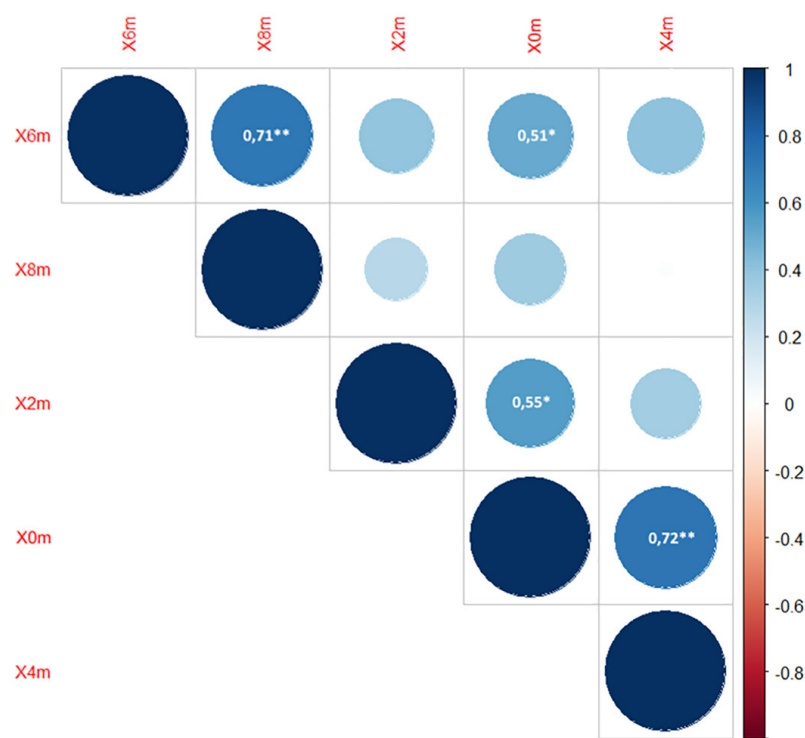

Figure 2 - Color scale matrix and Pearson correlation values of flight heights. Significance $\left({ }^{*}, 0.05 ;{ }^{* *}, 0.01\right)$

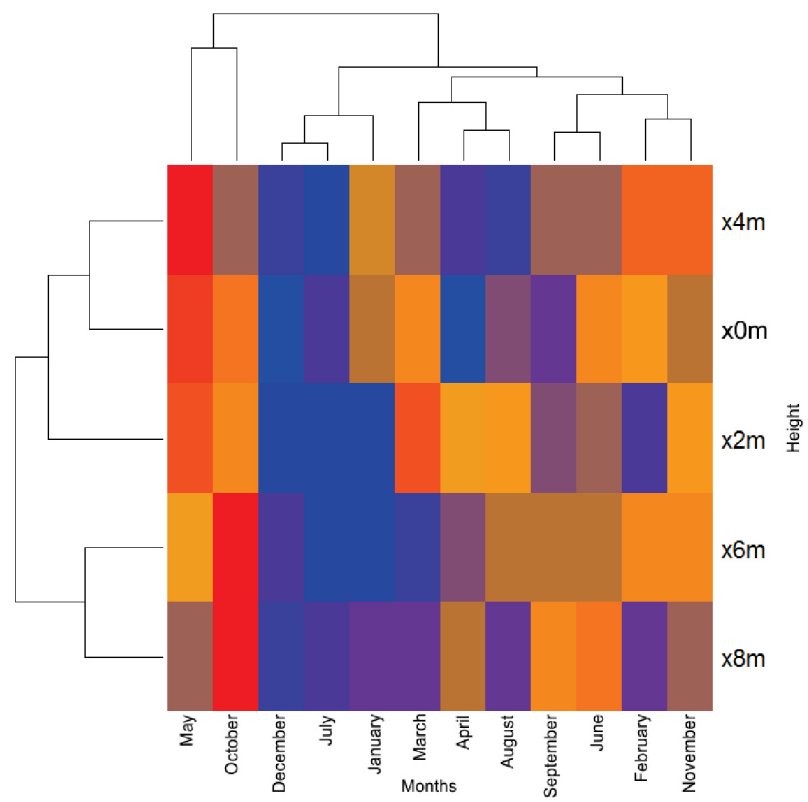

Figure 3 - Color map with cluster grouping. Correlation between flight heights and - observation months

the species to adapt to local environmental conditions, as well as the need for constant surveillance. Despite the fact that the State of Rio de Janeiro is considered outside the area affected by yellow fever, the virus has recently been spreading to the Southern and Southeastern Brazil $^{11,12,26}$.

In a previous study, Guimarães and Arlé27 found that Hg. leucocelaenus is most abundant during November and June, which is similar to our observation that the species is more abundant during October and May.

Alencar et al..$^{18}$ observed that $H g$. leucocelaenus, Oc. terrens, and $\mathrm{Hg}$. janthinomys possess a certain tolerance to desiccation. This suggests that egg dormancy and drought resistance are reproductive strategies that ensure the longterm survival of mosquito species that develop in temporary nurseries, such as treeholes and other cavities, and that they are subjected to water level fluctuations ${ }^{6}$. Egg diapause involves the long and stable delay of eclosion, even under favorable environment conditions. The diapause of eggs from members of the Aedini is usually terminated during the first immersion, but some eggs may need more than one immersion to eclose ${ }^{28}$. This is known as installment hatching ${ }^{29}$ and is probably a survival strategy, as in Haemagogus species, which grow in temporary nurseries subjected to frequent inundation and desiccation ${ }^{30}$. This means that some of the eggs need to be submerged several times to eclode and a single oviposition can generate offsprings over a long period.

In the present work, more eggs were observed in October than in any other month. Considering the time needed for the eggs to complete diapause and fully develop, it is interesting to note that the emergence of the highest number of adults probably coincides with summer. In Brazil, yellow fever transmission occurs mainly between November and May, which may be explained by the occurrence of subsequent rain that submerges the deposited egg ${ }^{31}$. Meanwhile, the second highest number of eggs was observed during May. Using the previous reasoning, we may explain the presence of adults during the remaining period of the year.

Interestingly, eggs were collected regardless of month or trap height, and no significant difference was observed between month or trap height. This demonstrates that females of this $\mathrm{Hg}$. leucocelaenus population were not selective regarding niches along the vertical plane, and it is possible that blood meals occur at diverse height levels, as well. This plasticity may have reproductive and epidemiological consequences. From a reproductive point of view, exploring the entire vertical plane may increase

Table 2 - Analysis of variance (ANOVA) considering the months as treatments and the heights as repetitions for each month

\begin{tabular}{lccccc}
\hline & df & Sum Sq & Mean Sq & Critical F* & Pr $(>\mathrm{F})$ \\
\hline Treatment & 11 & 104,793 & 9527 & $\mathbf{1 . 9 9 4 6}^{\star \star *}$ & $0.00011^{* \star *}$ \\
Residuals & 48 & 100,936 & 2103 & & \\
\hline
\end{tabular}

Significance $\left.{ }^{* * *}, p<0.001\right)$ 
the chances of finding suitable nurseries and blood-meal sources. From an epidemiological point of view, the exploration of the different strata may enable females to transmit pathogens to a variety of host species. This is particularly relevant for the transmission of wild yellow fever to arboreal primates, the main hosts.

Overall, the transmission of yellow fever virus occurs inside forests, mainly infecting working men (e.g., lumberjacks, fishermen, and hunters). However, $\mathrm{Hg}$. albomaculatus is not restricted to forest habitats and, as a result, may infect humans of both sexes and of various ages ${ }^{32}$. Yellow fever-carrying Hg. leucocelaenus were also captured at ground levels during the great yellow fever outbreak that occurred in Rio Grande do Sul State, Brazil, between 2008 and $2009^{12}$, thereby supporting our hypothesis.

Despite the similar number of eggs observed at different heights, a significant and positive correlation was observed between height and absolute abundance, which may indicate that the sensitivity to oviposition traps tends to increase with height in particular from 0 to $4 \mathrm{~m}$ and from 6 to $8 \mathrm{~m}$. Davis ${ }^{33}$, Trapido et al. ${ }^{34}$, Galindo et al..$^{35}$, and Fé et al.$^{36}$ observed that $\mathrm{Hg}$. leucocelaenus is more abundant in the canopy, thereby demonstrating its tendency to acrodendrophily. However, this was not observed by Causey and Dos Santos ${ }^{37}$, Forattini et al..$^{38}$ and Mondet $^{39}$, who found that the species was more abundant at the ground level. The present study did not observe a preference for any height.

The cluster analysis indicated that abundance was similar between non-adjacent months that had different climate conditions, an observation that coincides with the fact that climate conditions (temperature, rainfall, and humidity) had no effect on abundance. Therefore, the findings of the present study suggest that the availability of resources (nursery sites and blood meals) is the main drivers of female abundance at different levels. Indeed, the availability of nursery sites has been considered by several authors as the main factor affecting female Culicidae dispersion.

According to Alencar et al. ${ }^{40} \mathrm{Hg}$. leucocelaenus is an opportunistic species with eclectic feeding habits that is likely to influence the species mobility between the canopy and the ground level. Even though the region under study has no active records of wild yellow fever transmission, we suggest that the high abundance of major virus vectors justify a special surveillance regarding the emergence of febrile diseases among the inhabitants of the surrounding communities.

\section{REFERENCES}

1. Bentley MD, Day JF. Chemical ecology and behavioral aspects of mosquito oviposition. Annu Rev Entomol. 1989;34:401-21.
2. Onyabe DY, Roitberg BD. The effect of conspecifics on oviposition site selection and oviposition behaviour in Aedes togoi (Theobold)(Diptera: Culicidae). Can Entomol. 1997;129:1173-6.

3. Spencer M, Blaustein L, Cohen JE. Oviposition habitat selection by mosquitoes (Culiseta longiareolata) and consequences for population size. Ecology. 2002;83:669-79.

4. Resetarits WJ Jr. Oviposition site choice and life history evolution. Am Zool. 1996;36:205-15.

5. Harrington LC, Ponlawat A, Edman JD, Scott TW, Vermeylen F. Influence of container size, location, and time of day on oviposition patterns of the dengue vector, Aedes aegypti, in Thailand. Vector Borne Zoonotic Dis. 2008;8:415-23.

6. Vinogradova EB. Diapause in aquatic insects, with emphasis on mosquitoes. In: Alekseev VR, de Stasio BT, Gilbert JJ, editors. Diapause in aquatic invertebrates, theory and human use. New York: Springer; 2007. p.83-113.

7. Arnell JJ. Mosquito studies (Diptera, Culicidae). XXXII. A revision of the genus Haemagogus. Contrib Am Entomol Inst. 1973;10:1-174.

8. Forattini OP, Gomes AC, Natal d, Kakitani I, Marucci D. Preferências alimentares e domiciliação de mosquitos Culicidae no Vale do Ribeira, São Paulo, Brasil, com especial referência a Aedes scapularis e a Culex (Melanoconion). Rev Saúde Pública. 1989;23:9-19.

9. Marcondes CB, Alencar J. Revisão de mosquitos Haemagogus Williston (Diptera: Culicidae) do Brasil. Rev Biomed. 2010;21:221-38.

10. Camargo-Neves VL, Poletto DW, Rodas LA, Pachioli L, Cardoso RP, Scandar SA, et al. Entomological investigation of a sylvatic yellow fever area in Sao Paulo State, Brazil. Cad Saúde Pública. 2005;21:1278-86.

11. Vasconcelos PF, Sperb AF, Monteiro HA, Torres MA, Souza $\mathrm{MR}$, Vasconcelos HB, et al. Isolations of yellow fever virus from Haemagogus leucocelaenus in Rio Grande do Sul State, Brazil, in the Southern Cone. Trans R Soc Trop Med Hyg. 2003;97:60-2.

12. Cardoso JC, Almeida MA, Santos E, Fonseca DF, Sallum MA, Noll CA, et al. Yellow fever virus in Haemagogus leucocelaenus and Aedes serratus mosquitoes, Southern Brazil, 2008. Emerg Infect Dis. 2010;16:1918-24.

13. Figueiredo ML, Gomes AC, Amarilla AA, Leandro AS, Orrico AS, Araujo RF, et al. Mosquitoes infected with dengue viruses in Brazil. Virol J. 2010;7:152.

14. Moreno ES, Spinola R, Tengan CH, Brasil RA, Siciliano MM, Coimbra TL, et al. Yellow fever epizootics in non-human primates, São Paulo state, Brazil, 2008-2009. Rev Inst Med Trop Sao Paulo. 2013;55:45-50.

15. Saad LD, Barata RB. Yellow fever outbreaks in São Paulo State, Brazil, 2000-2010. Epidemiol Serv Saúde. 2016;25:53140. 
16. Ribeiro M, Antunes CM. Febre amarela: estudo de um surto. Rev Soc Bras Med Trop. 2009;42:523-31.

17. Fundação Instituto Oswaldo Cruz. Relatório ambiental do Setor 1 da Colônia Juliano Moreira. Rio de Janeiro: FIOCRUZ; 2004.

18. Alencar J, Morone F, Mello CF, Gil-Santana HR, Guimarães AE. Immature mosquitoes (Diptera: Culicidae) in a eutrophic landfill tank from State of Rio de Janeiro, Brazil. Rev Soc Bras Med Trop. 2013;46:769-71.

19. Alencar J, Gleiser RM, Morone F, Mello CF, Silva JS, Serra Freire NM, et al. A comparative study of the effect of multiple immersions on Aedini (Diptera: Culicidae) mosquito eggs with emphasis on sylvan vectors of yellow fever virus. Mem Inst Oswaldo Cruz. 2014;109:114-7.

20. Alencar J, Mello CF, Gil-Santana HR, Guimarães AE, Almeida SA, Gleiser RM. Vertical oviposition activity of mosquitoes in the Atlantic Forest of Brazil with emphasis on the sylvan vector, Haemagogus leucocelaenus (Diptera: Culicidae). J Vector Ecol. 2016;4:18-26.

21. Silver JB. Mosquito ecology: field sampling methods. $3^{\text {rd }}$ ed. New York: Springer; 2008.

22. Fay RW, Perry AS. Laboratory studies of ovipostional preferences of Aedes aegypti. Mosq News. 1965;25:276-81.

23. Fay RW, Eliason DA. A preferred oviposition site as a surveillance method for Aedes aegypti. Mosq News. 1966;26:531-5.

24. Forattini OP. Culicidologia médica. São Paulo: EDUSP; 19962002. v.2.

25. The R Project for Statistical Computing. [cited 2017 Mar 3]. Available from: https://www.r-project.org/

26. Souza RP, Petrella S, Coimbra TL, Maeda AY, Rocco IM, Bisordi I, et al. Isolation of yellow fever virus (YFV) from naturally infectied Haemagogus (Conopostegus) leucocelaenus (Diptera, Cukicudae) in São Paulo State, Brazil, 2009. Rev Inst Med Trop Sao Paulo. 2011; 53:133-9.

27. Guimarães AE, Arlé M. Mosquitos no Parque Nacional da Serra dos Órgãos, estado do Rio de Janeiro, Brasil: I-distribuição estacional. Mem Inst Oswaldo Cruz. 1984;79:309-23.

28. Clements AN. The physiology of mosquitoes. Oxford: Pergamon; 1963.

29. Gillett JD. Variation in the hatching response of Aedes eggs (Diptera: Culicidae). Bull Entomol Res. 1955;46:241-54.
30. Andreadis TG. Observations on the installment egg hatching in the brown salt marsh mosquito, Aedes cantator. J Am Mosq Control Assoc. 1990;6:727-9.

31. Costa ZG, Romano AP, Elkhoury AN, Flannery B. Evolução histórica da vigilância epidemiológica e do controle da febre amarela no Brasil. Rev Pan-Amaz Saude. 2011;2:11-26.

32. Hervé JP, Dégallier N, Travassos da Rosa AP, Pinheiro FP, Sá GC. Aspectos ecológicos. In: Instituto Evandro Chagas: 50 anos de contribuição às ciências biológicas e à medicina tropical. Belém: Ministério da Saúde: Fundação Serviços de Saúde Pública; 1986.

33. Davis ED. Larval habitats of some Brazilian mosquitoes. Rev Entomol. 1944;15:221-35.

34. Trapido H, Galindo P, Carpenter SJ. A survey of forest mosquitoes in relation to sylvan yellow fever in the Panama isthmian area. Am J Trop Med Hyg. 1955;4:525-42.

35. Galindo P, Carpenter SJ, Trapido H. A contribution to the ecology and biology of tree hole breeding mosquitoes of Panama. Ann Entomol Soc Am. 1955;48:158-64.

36. Fé NF, Barbosa MD, Fé FA, Guerra MV, Alecrim WD. Fauna de Culicidae em municípios da zona rural do Estado do Amazonas, com incidência de febre amarela. Rev Soc Bras Med Trop. 2003;36:343-8.

37. Causey OR, Santos GV. Diurnal mosquitoes in an area of small residual forests in Brazil. Ann Entomol Soc Am. 1949;42:47182.

38. Forattini OP, Lopes OS, Rabello EX. Investigações sobre o comportamento de formas adultas de mosquitos silvestres no Estado de São Paulo, Brasil. Rev Saúde Pública. 1968;2:11173.

39. Mondet B, Vasconcelos PF, Travassos da Rosa AP, Travassos da Rosa ES, Rodrigues SG, Travassos da Rosa JF, et al. Isolation of yellow fever virus from nulliparous Haemagogus (Haemagogus) janthinomys in eastern Amazonia. Vector Borne Zoonotic Dis. 2002;2:47-50.

40. Alencar J, Barreto-Pacheco J, Serra-Freire N, Guimarães A, Bosch I. Comparative morphometric study of populations of Haemagogus leucocelaenus (Dyar \& Shannon, 1924) (Diptera: Culicidae), sylvatic vector of yellow fever virus in Brazil. Rev Ci Vida. 2008;28:23-8. 